\title{
The Use of Wild Plants for Food: a National Scale Analysis for Burkina Faso (West Africa)
}

\author{
Received: 2018-12-08; accepted: 2018-12-14
}

\author{
Karen Hahn', Marco Schmidt ${ }^{2,3}$, Adjima Thiombiano ${ }^{4}$ \\ ${ }^{1}$ Goethe University Frankfurt am Main, Institute of Ecology, Evolution and Diversity, Max-von-Laue Str. 13, 60438 Frank- \\ furt am Main, Germany \\ ${ }^{2}$ Senckenberg Biodiversität und Klima Forschungszentrum (SBiK-F), Daten- und Modellierzentrum, Senckenberganlage 25 , \\ 60325 Frankfurt, Germany \\ ${ }^{3}$ Palmengarten der Stadt Frankfurt, Wissenschaftlicher Dienst, Siesmayerstraße 61, 60323 Frankfurt, Germany \\ ${ }^{4}$ University of Ouagadougou, UFR-SVT, Department of Plant Biology and Physiology, Laboratory of Plant Biology and \\ Ecology, 09 BP 848, Ouagadougou 09, Burkina Faso \\ *corresponding author, e-mail address: karen.hahn@bio.uni-frankfurt.de
}

\begin{abstract}
Summary: Edible wild plants are an important supplement to the diets and livelihoods of rural households in West Africa. Despite their role in improving diets, mitigating famine periods and generating income there is a lack of extensive information on their uses for broader areas. Based on ethnobotanical records, we investigated wild food plants on the national scale of Burkina Faso, to provide a comprehensive overview of all edible plants, their taxonomy, plant parts and preparations. Our study revealed a relatively high number of 354 edible wild species, representing 66 plant families, with Fabaceae and Poaceae being the most species rich. Almost one third of these species have two to four edible plant parts. The number of species with edible fruits ranked highest, followed by seeds, leaves, starchy underground storage organs and others. Overall, the results underline that wild plant species contribute considerably to nutrition and the database compiled in this study constitutes a good basis for further evaluations of the potential of edible plants in Burkina Faso.
\end{abstract}

Keywords: wild food plants, edible plant parts, rural livelihoods, Burkina Faso, West Africa

\section{L'Utilisation des PLANTES SAUVAges POUR L'ALIMENTATION : UNE ANALYSE À L'ÉChELLE NATIONALE POUR LE BURKINA FASO (AFRIQUE DE L'OUEST)}

Résumé: Les plantes sauvages comestibles constituent un complément important à l'alimentation et aux moyens de subsistance des ménages ruraux d'Afrique de l'Ouest. Malgré leur rôle d'amélioration des régimes alimentaires, d'atténuation des périodes de famine et de génération de revenus, il manque d'informations détaillées sur leurs utilisations pour des zones larges. Nous avons étudié les plantes alimentaires sauvages à l'échelle nationale du Burkina Faso, sur la base des informations ethnobotaniques, afin de fournir un aperçu complet de toutes les plantes comestibles, de leur taxonomie, de leurs parties comestibles et de leurs préparations. Notre étude a révélé un nombre relativement élevé de 354 espèces sauvages comestibles, représentant 66 familles, les Fabaceae et Poaceae étant les plus riches en espèces. Près d'un tiers de ces espèces ont de deux à quatre parties de plantes comestibles. Le nombre d'espèces à fruits comestibles est le plus élevé, suivi des graines, des feuilles, des organes de stockage souterrains féculents et autres. Dans l'ensemble, les résultats soulignent que les espèces comestibles de plantes sauvages contribuent considérablement à la nutrition et que la base de données compilée dans notre étude constitue une bonne base pour des évaluations ultérieures du potentiel des plantes comestibles au Burkina Faso.

Mots-clés: plantes alimentaires sauvages, parties de plantes comestibles, moyens de subsistance en milieu rural, Burkina Faso, Afrique de l'Ouest

\section{Die Verwendung von Wildpflanzen als Nahrung: eine nationale Analyse für Burkina Faso (WESTAFRIKA)}

Zusammenfassung: Essbare Wildpflanzen sind eine wichtige Ergänzung der Ernährung und des Lebensunterhalts ländlicher Haushalte in Westafrika. Trotz ihrer Rolle, die Ernährung zu verbessern, Hungerperioden abzumildern und Einkommen zu generieren, fehlen für größere Gebiete umfangreiche Informationen über ihre Verwendung. In unserer Studie untersuchten wir die essbaren Wildpflanzen der Flora von Burkina Faso anhand ethnobotanischer Aufzeichnungen, um einen umfassenden Überblick über alle essbaren Pflanzen, ihre Taxonomie, Pflanzenteile und Zubereitungen auf nationaler Ebene zu geben. Unsere Studie zeigte eine relativ hohe Anzahl von 354 essbaren Wildpflanzen aus 66 Pflanzenfamilien auf, wobei Fabaceae und Poaceae die artenreichsten Familien sind. Fast ein Drittel dieser Arten besitzt zwei bis vier essbare Pflanzenteile. Die Anzahl der Arten mit essbaren Früchten ist am höchsten, gefolgt von Samen, Blättern, stärkehaltigen unterirdischen Speicherorganen und anderen Pflanzenteilen. Insgesamt unterstreichen die Ergebnisse, dass Wildpflanzenarten einen wesentlichen Beitrag zur Ernährung leisten und die im Rahmen dieser Studie erstellte Datenbank eine gute Grundlage für weitere Bewertungen des Potenzials essbarer Pflanzen in Burkina Faso darstellt.

Schlagworte: essbare Wildpflanzen, essbare Pflanzenteile, ländlicher Lebensunterhalt, Burkina Faso, Westafrika 


\section{INTRODUCTION}

In many African countries harvesting of wild edible plants is still an essential component of livelihoods of rural communities. They serve to improve daily diets, help to overcome periods of food shortages and generate income (VINCETI et al. 2018, ChivANDi \& al. 2015). Wild food species are particularly important for poorest households (Heubach et al. 2011) and especially women and children, who are the main harvesters (Bvenura \& Afolayan 2015, Teketay \& al. 2010). Despite this importance the knowledge about edible plant species is still inadequately documented. Information on the edibility of single species can be found in various online data bases (Oyen \& Lemmens 2002, Royal Botanic Gardens, Kew 1999) and literature sources (e.g. ARBONNIER 2000, BURKILL 1985-2000). Other studies address the use of wild food plants in locally restricted case studies (VINCETI \& al. 2018, Lessmeister \& al. 2015, 2018, Нeubach \& al. 2013, KÉRÉ 1998), focus on certain edible plant parts like fruits and vegetables (VINCETI \& al. 2018, GAisberger \& al. 2017, StadLmayr \& al. 2013), deal with woody species only (SiegLSTETTER \& al. 2011) or investigate single multipurpose tree species (SCHUMANN \& al. 2010, HAARMEYER $\&$ al. 2013). However, extensive assessments of edible plant species covering larger areas are rare (TEKETAY \& al. 2010). For Burkina Faso, a first more general quantification of plant use revealed that $21 \%$ of the known flora (2067 species, Thiombiano \& al. 2012) is used for human nutrition (ZIzKA \& al. 2015a). However, this analysis included also cultivated plants and no further information on e.g. the share of plant parts or preparations is given, which would enable more insights into the potentials of edible plant food resources.

The objective of this study is a comprehensive analysis of wild food plants of the entire flora of Burkina Faso. We analysed the diversity, taxonomy, life forms, used plant parts and preparations of edible species based on ethnobotanical records of the checklist of Burkina Faso (Thiombiano \& al. 2012). This overview provides a first basis for the national scale to assess the full potential of edible wild plants and to serve for further studies in regard to sustainable use and conservation.

\section{Methods}

All wild plant species for which human nutrition was recorded in the checklist of Burkina Faso (Thiombiano \& al. 2012) were compiled. The information on human nutrition was categorized for the type of edible plant organs and their preparations. The type of edible organ contained the categories bark, branch, bud, bulb, bulbil, corm, flower, fruit, gum, leaf, rhizome, root, sap, seed, shoot, tuber, whole plant, and unknown. The category fruit was additionally subdivided into fruits with (partly) fleshy or dry pericarp to provide more indications on nutrition potentials. This information was available via the FLOPO knowledge base (HöHNDORF $\&$ al. 2018), and is based on trait data of the identification keys of the African Plants photo guide (DRESSLER \& al. 2014). The type of preparation was categorised into cereal, other mainly starchy side dishes, drink, fresh, oil, sauce/ soup, spice, sweets, vegetable, other (not specified). Fur- thermore, we categorised the 'edibility state', whether a plant part is eaten raw, cooked, roasted, burnt or processed (for detoxification). Plant family and lifeform information was taken from Thiombiano \& al. (2012), distribution (vegetation zones Sahel and Sudan) is based on records from THIOMBIANO \& al. (2012) using the province based schema from ZIZKA \& al. (2015b; Fig.1). In case of lacking information on plant parts or preparations a Google search query was conducted (e.g. online databases FERN 2014, OYEN \& LEMMENS 2002) to complete the records.

\section{Results ANd Discussion}

Out of the known 1972 wild plant species of Burkina Faso (ZizKA \& al. 2015b) 352 species (17.8\%) had a documented use as food plant. This is compared to other savanna dominated countries a considerably high species number. For Kenya, for example, 175 species were recorded (MAUNDU \& al. 1999), for Tanzania 326 species (RUFFo \& al. 2002), and for the much more species rich Ethiopian flora, comprising a high variety of vegetation types, 378 edible wild species (Teketay \& al. 2010).

For all food plant species details on the life form, edible plant parts, preparations, edibility states and distribution are given in the electronic supplement. In total 505 uses of edible plant parts (EPPs) are recorded for the species in Burkina Faso. Thus, many species provide more than one edible plant part (Fig.1). For 31 species three to four plant parts are edible (Table 1). Most of these multi-use species belong to phanerophytes, often having edible fruits, leaves and seeds; but surprisingly also some geophytes (e.g. Dioscorea praehensilis) and the grass species Imperata cylindrica and Phragmites australis belong to this group. They provide often edible leafs, shoots and roots, tubers or rhizomes.

For 77 species a use of two EPPs was recorded, most of them belong also to phanerophytes and geophytes. Thus, particularly woody species and geophytes play a prominent role for multi-use of edible plant parts. The large majority of species (246 species), however, has only one edible plant part and these species are represented in all life form categories (Fig.1).

The use for nutrition is highly related to plant taxonomy. Most edible plants in Burkina Faso are angiosperms, except for two species of ferns (Marsilea minuta, Ophioglossum reticulatum). The species with edible plant parts belong to a large number of 66 different plant families (Appendix Table 2 ). However, many of these families contribute only with very few species and/or EPPs. The 10 most important plant families containing more than 10 species respectively and at least 15 EPPs are shown in figure 2. They comprised together 210 species and $60.4 \%$ (total number of EPPs: 305 ) of all recorded edible plant parts. Families with the highest number of edible species/EPPs were the Fabaceae and Poaceae, containing together $27.5 \%$ of all recorded EPPs. They are the most species rich families of Burkina Faso (ZIZKA \& al. 2015b) and - including some of the world food crops are also of special importance for human nutrition on a global level. 


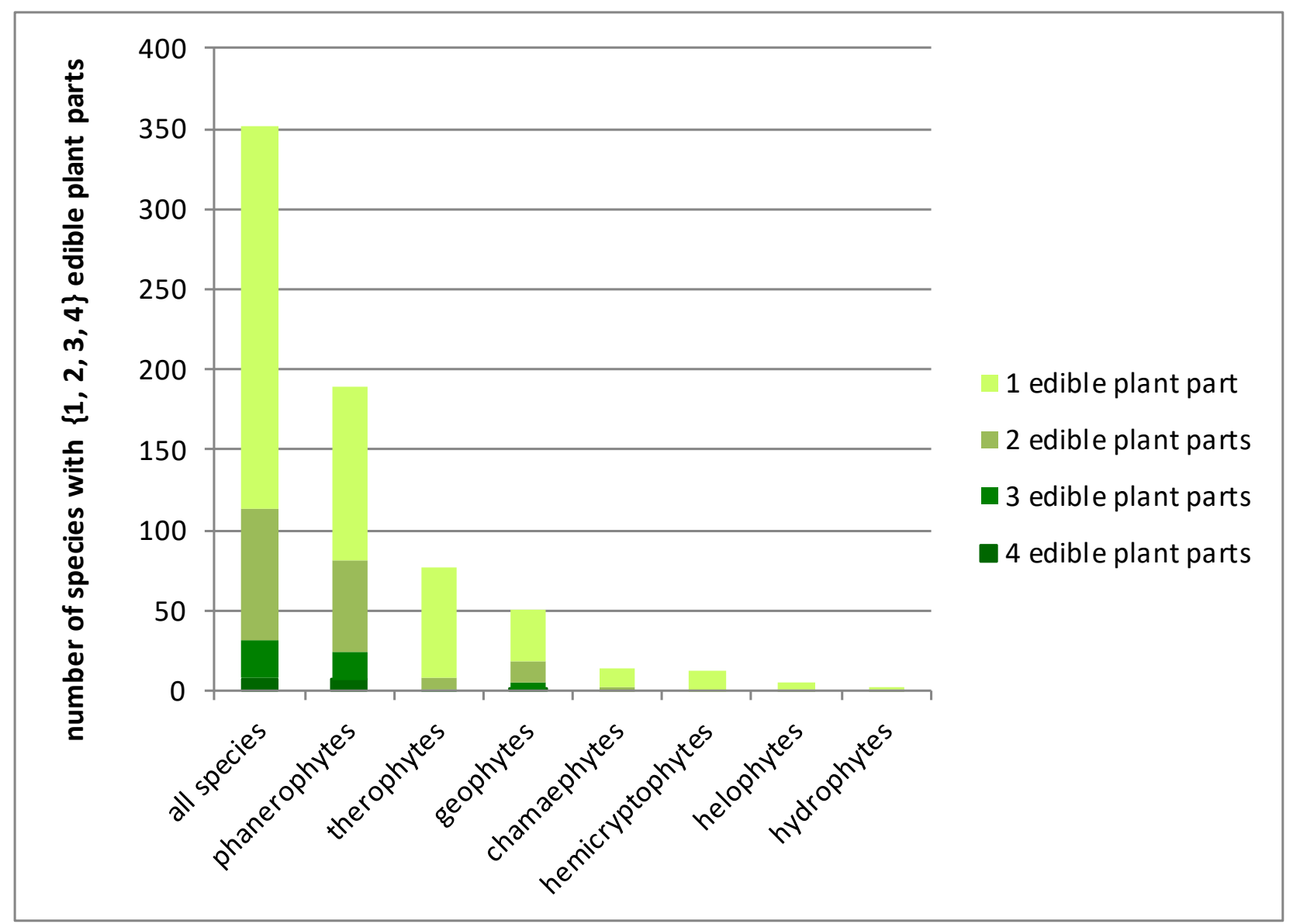

Fig. 1: Number of edible plant parts (EPPs) per species for all species and according to life forms / Nombre de parties de plantes comestibles (PPE) par espèce pour toutes les espèces et selon les types biologiques / Anzahl der essbaren Pflanzenteile (EPPs) pro Art für alle Arten und Lebensformen

Intriguingly, the plant families show a high variation with regard to the number of different EPPs (Fig.2). While Fabaceae species provide edible fruits, seeds and leaves in almost equally high numbers and contain also some species with edible underground storage organs (USOs: bulbs, corms, rhizomes, roots) and other plant parts, Poaceae species provide principally edible seeds besides some other plant organs. Malvaceae and Capparaceae have higher numbers of species with both edible fruits and leaves, whereas Moraceae and Anacardiaceae comprise mainly species with edible fruits in higher numbers. Edible USOs are found mostly in the families Dioscoreaceae, Cyperaceae and Apocynaceae. Besides the top 10 families, also some other families have higher numbers of species with certain edible plant parts: edible fruits occur more often in the families Rubiaceae (9), Phyllanthaceae (8) and Annonaceae (5), edible USOs more often in the Araceae (8) and Iridaceae (3) families.

The share of plant parts is shown in figure 3. Overall, fruits are the most important plant part in terms of species richness (148 fruit providing species). The majority are (partly) fleshy (112 species) and are often eaten raw. Highly estimated are for example the fruits of the shea butter tree (Vitellaria paradoxa) or the false grape tree (Lannea microcarpa), which are even spared from chopping in fields because of their food value (HAARMEYER \& al. 2013, SCHUMANN \& al. 2012). Also some species with dry fruits are highly valued and preserved in fields, such as the locust bean tree (Parkia biglobosa), the baobab (Adansonia digitata) and Tamarindus indica (Schumann \& al. 2012, HeUbach \& al. 2016). All of them have a mealy and sweet fruit pulp, which is eaten raw or used for cooking, besides the seeds, which are either transformed into a mineral rich condiment (soumbala, Kronenborg \& al. 2014) or eaten raw (baobab seeds, LESSMEISTER \& al. 2015).

Seeds are the second most important edible plant part (Fig.3). Many of them are harvested from woody species and some are particularly estimated for their fat content, such as the shea butter tree, providing the most preferred and widely used fat in daily nutrition (LESSMEISTER et al. 2015, Maranz et al. 2004). Many other edible seeds are provided by grass species (e.g. Brachiara lata, Dactyloctenium aegyptium, Panicum laetum). They are either cooked as cereals or prepared into drinks and serve also often to overcome times of food shortages. Edible leaves are also provided by a relatively high number of species. They are mostly cooked as vegetables like spinach in daily sauces. Most important are leaves of some woody species, such as the young leaves of the baobab (SchumanN et al 2012) or leaves and whole plants of several herbaceous species, e.g. Amaranthus spinosus, Corchorus olitorius, Portulaca oleracea, Solanum nigrum (LessmeIster et al. 2015). The latter are widely used as wild vegetable species throughout SubSaharan Africa (Bvenura \& Sivakumar 2017). Also underground storage organs of a considerable number of species 


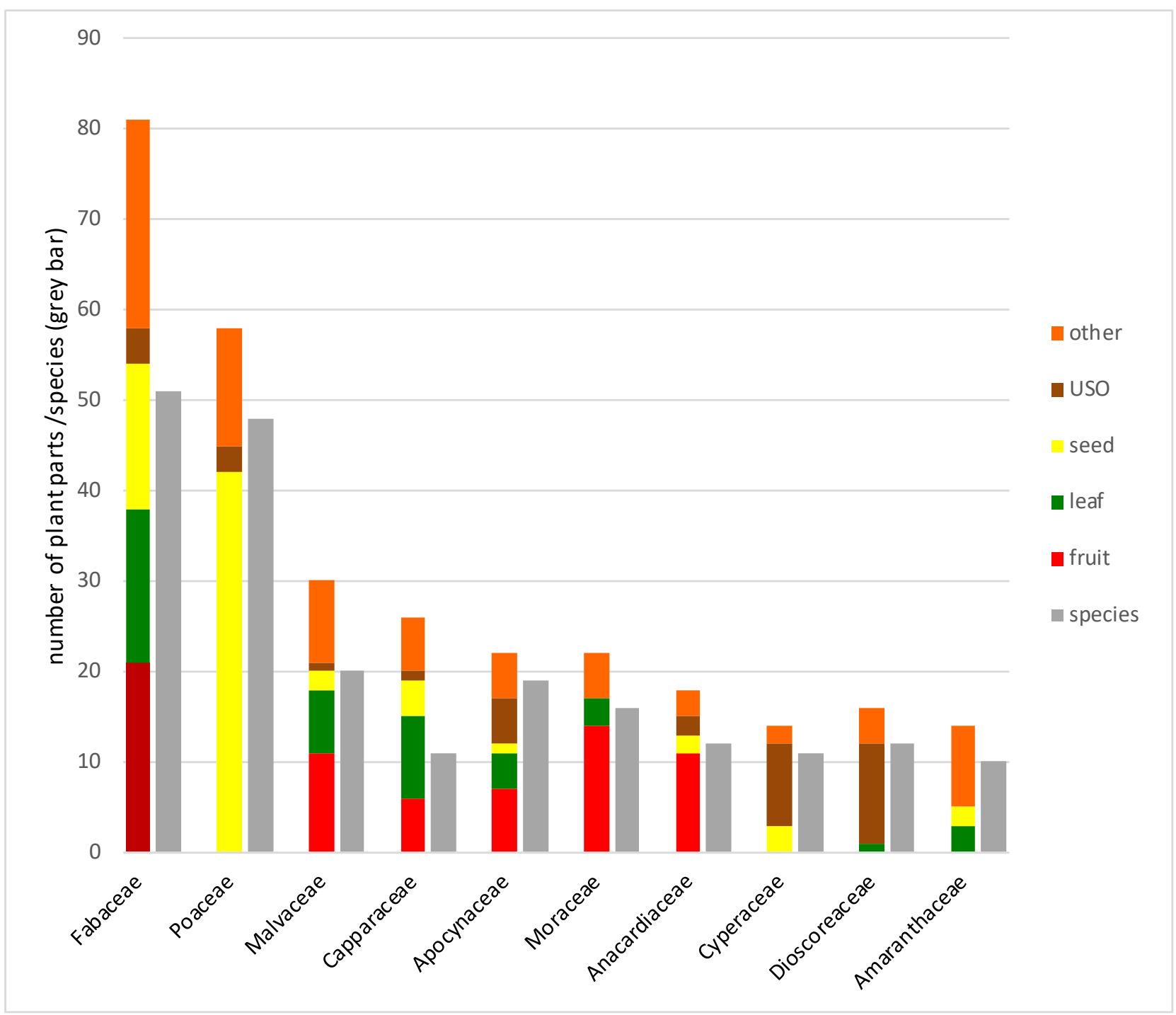

Fig. 2: The 10 most important plant families (more than 10 species respectively and at least 15 edible plant parts), and their share of plant parts. USO - Underground storage organs: tuber, root, rhizome and corm; other: bark, branch, bud, bulbil, flower, gum, sap, shoot, whole plant and unknown plant part / Les 10 familles de plantes les plus importantes (plus de 10 espèces respectivement et au moins 15 parties de plante comestibles), et leur part de parties de plante. USO - Organes de stockage souterrains: tubercule, racine, rhizome et corme; autre: écorce, branche, bourgeon, bulbille, fleur, gomme, sève, tige, plante entière et partie de plante inconnue / Die 10 wichtigste Pflanzenfamilien (jeweils mehr als 10 Arten und mindestens 15 essbare Pflanzenteile) und deren Anteil an Pflanzenteilen. USO - Unterirdische Speicherorgane: Knolle, Wurzel, Rhizom und Zwiebel; andere: Rinde, Zweig, Knospe, Bulbille, Blüte, Harz, Saft, Trieb, ganze Pflanze und unbekanntes Pflanzenteil.

are edible. They are mostly consumed as starchy side dishes (e.g. several wild yams species, Dioscorea spec.), but sometimes also eaten raw as snacks, such as some Cyperus species. However, some of the wild yam species and Araceae species need several day procedures (soaking in water, chopping, drying) for detoxification.

Other plant parts are only provided by a lower number of species. Edible flowers of phanerophytes are mainly eaten as sauce ingredients and some of them are frequently used, for example, the calyx of Bombax costatum (OUEDRAOGO et al. 2014). Gums of several species (mainly Acacia and Combretum species) are eaten raw as sweets and shoots; barks and branches are mostly consumed cooked as vegetables or spices in sauces and soups. Some branches and whole herbaceous plants are burnt to ash and added as salt or spice. Saps are only extracted out of very few species, such as the palms Borassus aethiopum and Elaeis guineensis, but are highly important for wine preparation (MOLLET \& al. 2000).

\section{CONCLUSION}

This analysis provides a first comprehensive overview on all recorded edible plants of the Flora of Burkina Faso. We found a relatively high diversity of wild food species and for almost one third of these even two to four edible plant parts per species. Edible fruits, followed by seeds and leaves, have the highest species diversity and contribute considerably to nutrition. But also other plant parts, such as starchy USOs, are provided by a higher number of species. The results underline the role of wild plant species as important food supplements and constitute a good basis for further evaluations of the potential of edible plants in Burkina Faso. Future research is needed to further identify the most important edible species and plant parts for the livelihoods of rural dwellers in a qualitative and quantitative perspective. Also their distributions and availabilities should be thoroughly investigated to estimate sustainable harvesting quantities. Moreover, the complete list of plant food resources is provided 
Table 1: List of species providing three to four edible plant parts / Liste des espèces fournissant trois à quatre parties de plantes comestibles / Liste der Arten mit drei bis vier essbaren Pflanzenteilen.

\begin{tabular}{|c|c|c|c|c|c|c|c|c|c|c|c|c|c|c|c|}
\hline & fruit & leaf & seed & shoot & bark & flower & root & branch & sap & gum & bud & $\begin{array}{c}\text { rhi- } \\
\text { zome }\end{array}$ & tuber & $\begin{array}{l}\text { whole } \\
\text { plant }\end{array}$ & Sum \\
\hline Acacia nilotica & 1 & & 1 & & 1 & & & & & 1 & & & & & 4 \\
\hline Acacia polyacantha & & & 1 & & & & & 1 & & 1 & & & & & 3 \\
\hline Adansonia digitata & 1 & 1 & 1 & & & & & & & & & & & & 3 \\
\hline Ampelocissus africana & 1 & 1 & & & & & 1 & & & & & & & & 3 \\
\hline Annona senegalensis & 1 & 1 & & & & 1 & & & & & & & & & 3 \\
\hline Balanites aegyptiaca & 1 & & 1 & 1 & & & & & & & & & & & 3 \\
\hline Borassus aethiopum & 1 & & & 1 & & & & & 1 & & & & & & 3 \\
\hline Boscia angustifolia & 1 & & 1 & & 1 & & & 1 & & & & & & & 4 \\
\hline Boscia salicifolia & & 1 & & & 1 & & 1 & & & & & & & & 3 \\
\hline Boscia senegalensis & 1 & 1 & 1 & & & & & 1 & & & & & & & 4 \\
\hline Cadaba farinosa & & 1 & & & 1 & 1 & & & & & & & & & 3 \\
\hline Ceiba pentandra & 1 & 1 & & & & 1 & & & & & & & & & 3 \\
\hline Commiphora africana & 1 & & & & & & 1 & & & 1 & & & & & 3 \\
\hline Cordia myxa & 1 & & 1 & & & 1 & & & & & & & & & 3 \\
\hline Crateva adansonii & 1 & 1 & 1 & & & & & & & & & & & & 3 \\
\hline Detarium microcarpum & 1 & 1 & 1 & & & & & & & & & & & & 3 \\
\hline Dioscorea praehensilis & & 1 & & 1 & & & & & & & & & 1 & & 3 \\
\hline Echinochloa stagnina & & & 1 & 1 & & & & & 1 & & & & & & 3 \\
\hline Elaeis guineensis & 1 & & 1 & & & & & & 1 & & & & & & 3 \\
\hline Ficus sycomorus & 1 & 1 & & & 1 & & & & & & & & & & 3 \\
\hline Ficus umbellata & 1 & 1 & & & & & & & & & 1 & & & & 3 \\
\hline Grewia mollis & & & & & 1 & 1 & 1 & 1 & & & & & & & 4 \\
\hline Imperata cylindrica & & & & 1 & & & 1 & & & & & 1 & & 1 & 4 \\
\hline Ipomoea cairica & & 1 & & 1 & & & & & & & & & 1 & & 3 \\
\hline Lippia multiflora & 1 & 1 & & & & 1 & & & & & & & & & 3 \\
\hline Parkinsonia aculeata & 1 & 1 & & & & 1 & & & & & & & & & 3 \\
\hline Philenoptera laxiflora & 1 & 1 & & & 1 & 1 & & & & & & & & & 4 \\
\hline Phoenix reclinata & 1 & & & 1 & & & & & 1 & & 1 & & & & 4 \\
\hline Phragmites australis & & & 1 & 1 & & & 1 & & & & & & & & 3 \\
\hline Phyllanthus muellerianus & 1 & 1 & & & 1 & 1 & & & & & & & & & 4 \\
\hline Smilax anceps & & 1 & & 1 & & & & & & & & 1 & & & 3 \\
\hline Xylopia aethiopica & 1 & & & 1 & 1 & & & & & & & & & & 3 \\
\hline Sum & 22 & 18 & 12 & 10 & 9 & 9 & 6 & 4 & 4 & 3 & 2 & 2 & 2 & 1 & 104 \\
\hline
\end{tabular}




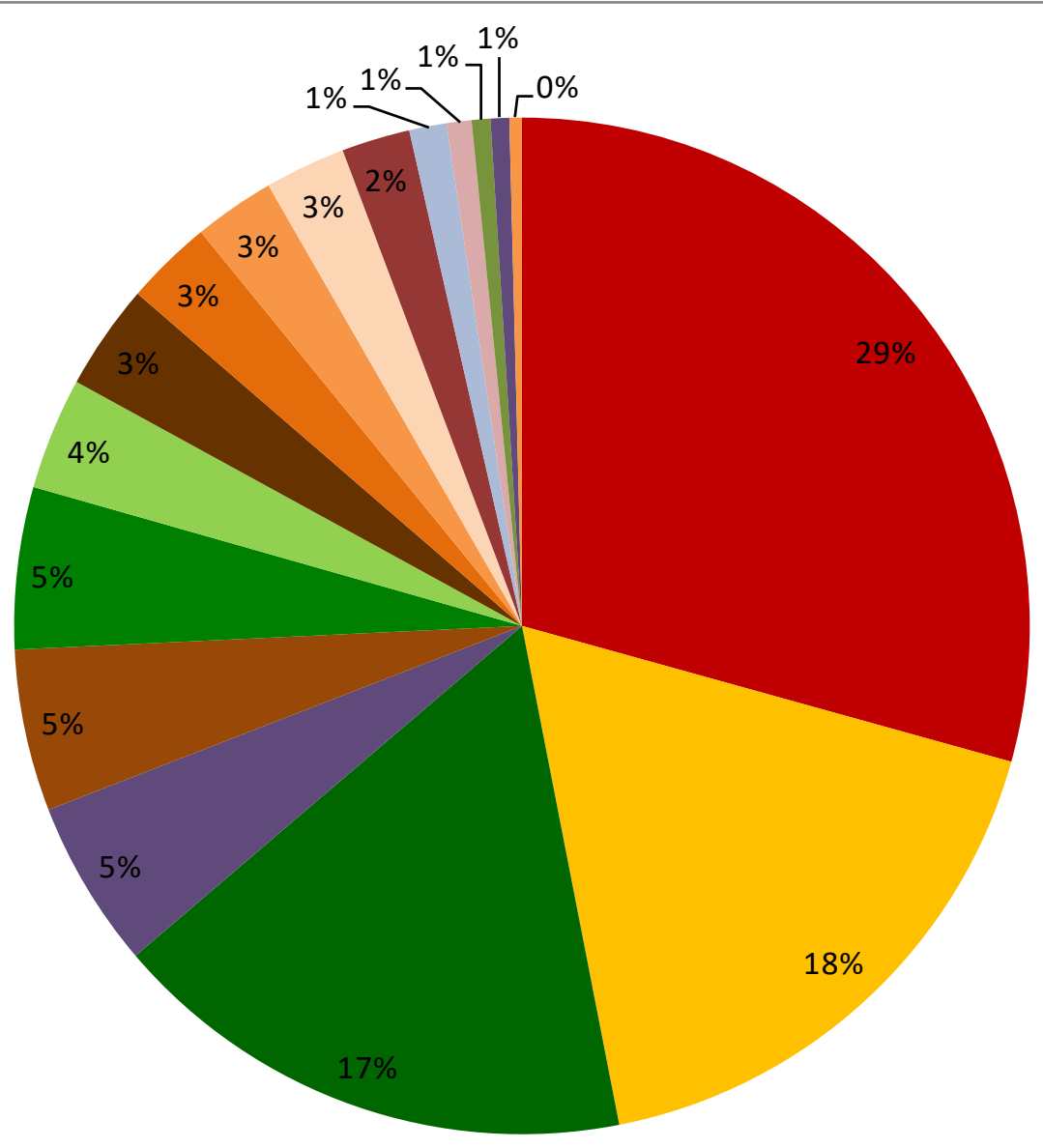

fruit
seed
leaf
flower
tuber
whole plant
shoot
bark
root
branch
gum
rhizome
sap
unknown
bulbil
corm
bud

Fig. 3: Share of edible plant parts (EPP) in percent of the total edible plant parts (505 EPPs) / Part des parties de plantes comestibles (PPE) en pourcentage du total des parties de plantes comestibles (505 PPE) / Anteil essbarer Pflanzenteile (EPP) in Prozent der gesamten essbaren Pflanzenteile (505 EPPs).

as an electronic supplement to this article and constitutes a basis for further investigations, e.g. regarding Neglected and Underutilized Species (NUS).

\section{REFERENCES}

ArbonNiER M (2000): Arbre, arbustes et lianes des zones sèches d'Afrique de l'Ouest. CIRAD, MNHN, UICN.

BuRkILl HM (1985-2000): The useful plants of West Tropical Africa. Vol 1-5. (Ed.2). Royal Botanic Gardens Kew.

Bvenura C \& Afolayan AJ (2015): The role of wild vegetables in household food security in South Africa: A review. Food Res Int 76: 1001-1011.

Bvenura C \& Sivakumar D (2017): The role of wild fruits and vegetables in delivering a balanced and healthy diet. Food Res Int 99: 15-30.

Chivandi E, Mukonowenzou N, Nyakudya T \& ErlwanGE KH (2015): Potential of indigenous fruit-bearing trees to curb malnutrition, improve household food security, income and community health in sub-Saharan Africa: A review. Food Res Int 76, 980-985.

Dressler, S, Schmidt M \& Zizka G (2014): Introducing African Plants - a Photo Guide - an interactive identification tool for continental Africa. Taxon. 63: 1159-1161.
FERN K (2014): Useful Tropical Plants Database. http://tropical.theferns.info/. Accessed 15.08. - 30.8.2018.

Gaisberger H, Kindt R, Loo J, Schmidt M, Bognounou F, Da SS, Diallo OB, Ganaba S, Gnoumou A, Lompo D ET AL. (2017): Spatially explicit multi-threat assessment of food tree species in Burkina Faso: A fine-scale approach. Bond-Lamberty B (ed.). PLoS One 12:e0184457.

HAARMEyer D, Schumann K, Bernhardt-RömermanN M, Wittig R, Thiombiano A \& Hahn K (2013): Human Impact on Population Structure and Fruit Production of the SocioEconomically Important Tree Lannea microcarpa in Burkina Faso. Agroforest Syst 87: 1363-1375.

Heubach A, Schumann K \& Hahn K (2016): Substitution patterns for seeds of Vitellaria paradoxa, Parkia biglobosa and Adansonia digitata used for nutrition by five major ethnic groups in Benin, West Africa. Flora Veg Sudano-Sambesica 19: 7-17.

Heubach K, Wittig R, Nuppenau EA \& Hahn K (2011): The economic importance of non-timber forest products (NTFPs) for livelihood maintenance of rural West African communities: A case study from northern Benin. Ecol Econ 70: 1991-2001.

Heubach K, Wittig R, Nuppenau EA \& Hahn K (2013): Local Values, Social Differentiation and Conservation Efforts: The Impact of Ethnic Affiliation on the Valuation of 
NTFP-Species in Northern Benin, West Africa. Hum Ecol 41: 513-533.

Hoenndorf R, Weiland C, Schmidt M, Groom Q, GosLine G, Dressler S \& Hamann T (2018): The Flora Phenotype Ontology (FLOPO) and the FLOPO Knowledgebase In: Thessen, A.E. (ed.). Appl Semant Technol Biodivers Sci. IOS Press, 107-119.

KÉRÉ U (1998): Vegetation und Wildpflanzennutzung in der Region Tenkodogo (Burkina Faso) / Végétation et utilisation des plantes sauvages de la région de Tenkodogo (Burkina Faso).- Études flor vég Burkina Faso 4: 3-55.

Kronborg M, Ilboudo JB, Bassolé IHN, Barfod AS, RavN HW \& LYKKe AM (2014): Correlates of Product Quality of Soumbala, a West African Non-timber Forest Product. Ethnobot Res Appl 12: 25-37.

Lessmeister A, Heubach K, Lykke AM, Thiombiano A, WitTIG R \& HAHN K (2018): The contribution of non-timber forest products (NTFPs) to rural household revenues in two villages in southeastern Burkina Faso. Agroforest Syst 92: 139-155.

Lessmeister A, Schumann K, Lykke AM, Heubach K, Thiombiano A \& Hahn K (2015): Substitution of the most important and declining wild food species in southeast Burkina Faso: Flora Veg Sudano-Sambesica 18: 11-20.

Maranz S, Kpikpi W, Wiesman Z, de Saint Sauveur A \& Chapagain B (2004): Nutritional values and indigenous preferences for shea fruits (Vitellaria paradoxa C.F Gaertn.F.) in African agroforestry parklands. Econ Bot 58: 588-600.

Maundu PM, NGugi GW, Kabuye CHS (1999): Traditional food plants of Kenya. National Museums of Kenya, Nairobi.

Mollet M, Herzog F, Behi YeN \& Farah Z (2000): Sustainable Exploitation of Borassus aethiopum, Elaeis guineensis and Raphia hookeri for the Extraction of Palm Wine in Côte d'Ivoire. Environ Dev Sustain 2: 45-59.

Ouédraogo I, Nacoulma BMI, Ouédraogo O, Hahn K \& Thiombiano A (2014): Productivité et valeur économique des calices de Bombax costatum Pellegr. \& Vuillet en zone soudanienne du Burkina Faso. Bois for trop 319(19): 31-41.

Oyen LPA \& LeMmens RHMJ (eds.) (2002): Plant Resources of Tropical Africa. Precursor. PROTA Programme, Wageningen, the Netherlands. https://www.prota4u.org. Accessed 15.08. - 30.8.2018.
Royal Botanic Gardens Kew (1999): Survey of Economic Plants for Arid and Semi-Arid Lands (SEPASAL) database. Published on the Internet; http://apps.kew.org/sepasalweb/ sepaweb. Accessed 15.08. - 30.8.2018.

Ruffo CK, Birnie A \& Tengnäs B (2002): Edible wild plants of Tanzania. RELMA, Nairobi.

Schumann K, Wittig R, Thiombiano A, Becker U \& HAHN K (2010): Impact of land-use type and bark- and leafharvesting on population structure and fruit production of the baobab tree (Adansonia digitata L.) in a semi-arid savanna, West Africa. For Ecol Manage 260: 2035-2044.

Schumann K, Wittig R, Thiombiano A, Becker U \& HAHN K (2012): Uses, management, and population status of the baobab in eastern Burkina Faso. Agroforest Syst 85: 263-278

Sieglstetter S, Hahn K \& Wittig R (2011): The use of woody species in northern Benin.- Flora Veg Sudano-Sambesica 14: 19-23.

Stadlmayr B, Charrondière UR, Eisenwagen S, JamnaDASSB R \& KEHLENBECK K (2013): Nutrient composition of selected indigenous fruits from sub-Saharan Africa. J Sci Food Agric 93: 2627-2636.

Teketay D, Senbeta F, Maclachlan M, Bekele M \& BarKLUND P (2010): Edible wild plants in Ethiopia. Addis Abeba, Addis Ababa University Press.

Thiombiano A, Schmidt M, Dressler S, Ouédraogo A, HAHN K \& ZizKA G (2012): Catalogue des plantes vasculaires du Burkina Faso. Boissiera 65, Geneva, Conservatoire et jardin botaniques de la ville de Genève.

Vinceti B, Termote C, Thiombiano N, Agúndez D \& LaMIEN N (2018): Food tree species consumed during periods of food shortage in Burkina Faso and their threats. Forest Syst 27(2): e006. https://doi.org/10.5424/fs/2018272-12157.

Zizka A, Thiombiano A, Dressler S, Nacoulma BMI, OuÉdraOgo A, OuÉDraogo I, OuÉdraogo O, ZizKa G, HAHN K \& SCHMidt M (2015a): Traditional plant use in Burkina Faso (West Africa): a national-scale analysis with focus on traditional medicine. J Ethnobiol Ethnomed 11: 9 doi:10.1186/1746-4269-11-9.

Zizka A, Thiombiano A, Dressler S, Nacoulma BMi, OuÉdraogo A, OuÉDraogo I, OuÉdraogo O, ZizKa G, HAHN K \& SchmidT M (2015b): The vascular plant diversity of Burkina Faso (West Africa) - a quantitative analysis and implications for conservation. Candollea 70: 9-20. 


\section{APPENDIX}

Table 2: List of plant families, their numbers of edible species and edible plant parts (EPPs) / Tableau 2: Liste des familles de plantes, leur nombre d'espèces comestibles et leurs parties. végétaux comestibles (EPP) / Tabelle 2: Liste der Pflanzenfamilien, Anzahl der essbaren Arten und essbaren Pflanzenteile (EPPs).

\begin{tabular}{|c|c|c|c|c|c|c|c|c|c|c|c|c|c|}
\hline & total species & total EPP & fruit & seed & leaf & USO & flower & whole plant & shoot & bark & branch & gum & other \\
\hline Sum & 352 & 505 & 148 & 89 & 85 & 54 & 27 & 26 & 18 & 17 & 13 & 13 & 15 \\
\hline Fabaceae & 51 & 81 & 21 & 16 & 17 & 4 & 6 & 2 & 1 & 3 & 4 & 6 & 1 \\
\hline Poaceae & 48 & 58 & & 42 & & 3 & & 4 & 7 & & & & 2 \\
\hline Malvaceae & 20 & 30 & 11 & 2 & 7 & 1 & 4 & 2 & & 1 & 1 & 1 & \\
\hline Capparaceae & 11 & 26 & 6 & 4 & 9 & 1 & 1 & & & 3 & 2 & & \\
\hline Apocynaceae & 19 & 22 & 7 & 1 & 4 & 5 & 3 & & & & 1 & & 1 \\
\hline Moraceae & 16 & 22 & 14 & & 3 & & & & & 4 & & & 1 \\
\hline Anacardiaceae & 12 & 18 & 11 & 2 & & 2 & & & & 2 & & 1 & \\
\hline Cyperaceae & 11 & 14 & & 3 & & 9 & & 2 & & & & & \\
\hline Dioscoreaceae & 12 & 16 & & & 1 & 11 & & & 1 & & & & 3 \\
\hline Amaranthaceae & 10 & 14 & & 2 & 3 & & & 7 & & & 2 & & \\
\hline Asteraceae & 10 & 11 & & & 6 & 1 & & 3 & 1 & & & & \\
\hline Rubiaceae & 10 & 13 & 9 & 2 & 2 & & & & & & & & \\
\hline Phyllanthaceae & 9 & 16 & 8 & & 3 & & 1 & & & 3 & 1 & & \\
\hline Araceae & 8 & 11 & & & 1 & 8 & 2 & & & & & & \\
\hline Combretaceae & 7 & 10 & 1 & 1 & 2 & & 1 & & & & 1 & 4 & \\
\hline Acanthaceae & 5 & 5 & & 2 & 1 & & & 2 & & & & & \\
\hline Annonaceae & 5 & 9 & 5 & & 1 & & 1 & & 1 & 1 & & & \\
\hline Arecaceae & 5 & 13 & 4 & 2 & & & & & 2 & & & & 5 \\
\hline Cucurbitaceae & 4 & 4 & 4 & & & & & & & & & & \\
\hline Lamiaceae & 4 & 5 & 3 & & 1 & & 1 & & & & & & \\
\hline Rhamnaceae & 4 & 5 & 4 & 1 & & & & & & & & & \\
\hline Sapotaceae & 4 & 5 & 4 & 1 & & & & & & & & & \\
\hline Boraginaceae & 3 & 5 & 2 & 1 & & & 1 & 1 & & & & & \\
\hline Convolvulaceae & 3 & 6 & & & 3 & 1 & & & 2 & & & & \\
\hline Iridaceae & 3 & 4 & & & & 3 & 1 & & & & & & \\
\hline Nymphaeaceae & 3 & 4 & 3 & & & 1 & & & & & & & \\
\hline Pedaliaceae & 3 & 3 & & 1 & 2 & & & & & & & & \\
\hline Sapindaceae & 3 & 3 & 3 & & & & & & & & & & \\
\hline Verbenaceae & 3 & 6 & 2 & & 2 & & 2 & & & & & & \\
\hline Vitaceae & 3 & 7 & 2 & & 3 & 1 & & & & & & & 1 \\
\hline Burseraceae & 2 & 4 & 2 & & & 1 & & & & & & 1 & \\
\hline Chrysobalanaceae & 2 & 3 & 2 & 1 & & & & & & & & & \\
\hline Euphorbiaceae & 2 & 3 & 1 & & 1 & & & & & & 1 & & \\
\hline Loganiaceae & 2 & 3 & 1 & & 1 & & 1 & & & & & & \\
\hline Meliaceae & 2 & 2 & 1 & 1 & & & & & & & & & \\
\hline Salicaceae & 2 & 2 & 2 & & & & & & & & & & \\
\hline Zingiberaceae & 2 & 4 & 2 & & 2 & & & & & & & & \\
\hline Bignoniaceae & 1 & 1 & 1 & & & & & & & & & & \\
\hline Bixaceae & 1 & 1 & & & & 1 & & & & & & & \\
\hline Caryophyllaceae & 1 & 1 & & & & & & 1 & & & & & \\
\hline Celastraceae & 1 & 2 & 1 & & 1 & & & & & & & & \\
\hline Cleomaceae & 1 & 1 & & & 1 & & & & & & & & \\
\hline Clusiaceae & 1 & 1 & & 1 & & & & & & & & & \\
\hline Connaraceae & 1 & 1 & 1 & & & & & & & & & & \\
\hline Costaceae & 1 & 1 & & & & & & & 1 & & & & \\
\hline Ebenaceae & 1 & 2 & 1 & & 1 & & & & & & & & \\
\hline
\end{tabular}




\begin{tabular}{|c|c|c|c|c|c|c|c|c|c|c|c|c|c|}
\hline & total species & total EPP & fruit & seed & leaf & USO & flower & whole plant & shoot & bark & branch & gum & other \\
\hline Marantaceae & 1 & 1 & 1 & & & & & & & & & & \\
\hline Marsileaceae & 1 & 1 & & & 1 & & & & & & & & \\
\hline Menispermaceae & 1 & 1 & 1 & & & & & & & & & & \\
\hline Myrtaceae & 1 & 1 & 1 & & & & & & & & & & \\
\hline Ochnaceae & 1 & 1 & 1 & & & & & & & & & & \\
\hline Olacaceae & 1 & 1 & 1 & & & & & & & & & & \\
\hline Oleaceae & 1 & 1 & 1 & & & & & & & & & & \\
\hline Ophioglossaceae & 1 & 1 & & & 1 & & & & & & & & \\
\hline Piperaceae & 1 & 1 & & & & & & & & & & & 1 \\
\hline Polygalaceae & 1 & 1 & & & & & 1 & & & & & & \\
\hline Polygonaceae & 1 & 1 & & & & & & 1 & & & & & \\
\hline Portulacaceae & 1 & 1 & & & 1 & & & & & & & & \\
\hline Rutaceae & 1 & 2 & & 1 & 1 & & & & & & & & \\
\hline Smilacaceae & 1 & 3 & & & 1 & 1 & & & 1 & & & & \\
\hline Solanaceae & 1 & 2 & 1 & & 1 & & & & & & & & \\
\hline Talinaceae & 1 & 1 & & & & & & 1 & & & & & \\
\hline Urticaceae & 1 & 1 & & & 1 & & & & & & & & \\
\hline Xanthorrhoeaceae & 1 & 1 & & & & & 1 & & & & & & \\
\hline Ximeniaceae & 1 & 2 & 1 & 1 & & & & & & & & & \\
\hline Zygophyllaceae & 1 & 3 & 1 & 1 & & & & & 1 & & & & \\
\hline
\end{tabular}

